\author{
Stanisław Liszewski \\ University of Łódź \\ Institut of Urban Geography and Tourism \\ stliszew@geo.uni.lodz.pl
}

\title{
TOURISM STUDIES: SITUATED WITHIN MULTIPLE DISCIPLINES OR A SINGLE INDEPENDENT DISCIPLINE? (DISCURSIVE ARTICLE)
}

\begin{abstract}
The article concerns the fundamentals of tourism studies and its methodology. After presenting the current situation, the author comments on the opinions of those whose aim it is to establish tourism studies as a fully independent discipline. This is followed by a presentation of the process of creating a 'tourism studies' which is not only multi-disciplinary, but above all an interdisciplinary basis for research. The article ends with a short reflection on the future of tourism studies and some conclusions. It is a discursive article.
\end{abstract}

Key words: tourism, the place of tourism research among other fields of knowledge, a single independent tourism studies discipline (nauka o turystyce), tourism studies within multiple disciplines (nauki o turystyce), multi-disciplinary and interdisciplinary research into tourism

\section{INTRODUCTION}

The last decade has witnessed great debate on the methodology and the theoretical basis of research into tourism. Numerous publications demonstrate interest in these issues: ALEJZIAK $(1999,2003,2008,2009)$, KAZIMIERCZAK (2005, 2010), CHOJNICKI (2005), GOŁEMBSKI ed. (2003), LISZEWSKI (1994, 2005), MAIK \& PRZYBECKAMAIK (2005), MAZURKIEWICZ (2005, 2009), WINIARSKI ed. (1999, 2004), WINIARSKI \& ALEJZIAK (2005), WOŹNIAK (2005), and others. The very number of works quoted, as well as the variety of disciplines represented, points to the growing intellectual ferment surrounding the place of tourism studies among academic disciplines. This is visible at conferences and seminars where such issues have caused many disagreements and much heated discussion. To consider only those organized in 2010, let us mention just two: the seminar held at the Academy of Physical Education in Poznań on $26^{\text {th }}$ March 2010, and the conference in Łódź, entitled 'Research and Teaching Methods (Nauka i dydaktyka) in Tourism and Recreation', which took place on 4-6 $6^{\text {th }}$ November 2010. Discussions from both those occasions were the direct inspiration for the writing of this article.

The main topics included content, issues and research methodology, as well as opinions on tourism and the place of tourism studies among other disciplines. There is no agreement whether we can talk today about an independent tourism discipline (nauka $o$ turystyce), or whether we are dealing with a very dynamic process of creating tourism studies among multiple disciplines (nauki o turystyce), or as WINIARSKI (2004) has put it: 'disciplines concerning themselves with tourism'.

CHOJNICKI (2005) has assessed the methodological context of tourism studies and classified it in the following ways:

- 'Tourism is a 'proto-discipline', so it does not meet all the prerequisites for becoming a fully-fledged academic one'

- 'It is studied empirically, but mainly in a descriptive and detail-focused way (not theoretical)'

- 'It is primarily a social science, based on the principles of an empirical model'

- 'It is a complex discipline. Its complexity can be observed on two levels: a) empirical - natural and social sciences, b) socio-economic, sociological, political, geographical, cultural, etc.'

- 'It is an applied discipline'

Prof. Chojnicki's position can be viewed as one expressed by an outsider dealing with the methodology of academic disciplines because he does not conduct research into tourism himself. His is then an attempt to describe tourism studies from the point of view of an epistemologist, and this enables us 
to move our discussions to a new, higher level of generality.

An additional topic is the relation between tourism and recreation. This emerged as a result of the establishment of such a specialisation in the mid1970's at some Polish Academies of Physical Education. Nowadays it is also taught at other universities e.g. in Łódź, Poznań, Szczecin and Lublin. Assuming there is a common field of study, MAZURKIEWICZ (2009) suggests establishing a single discipline of physical education (kulturze fizycznej) and tourism, and this would seem to be supported by KAZIMIERCZAK (2010).

We should also quote here an earlier view of ŁOBOŻEWICZ (2001) who, at the end of the $20^{\text {th }}$ C., saw tourism as a sub-discipline of physical education, defining it as 'purposeful activity in selected fields of tourism activities, appropriate to human needs'.

In our introduction to the general discussion we must mention the first Polish attempt, by the geographer LESZCZYCKI (1937), to provide an academic definition of tourism studies. In Komunikaty Studium Turyzmu UJ, tourism when 'considered in connection to spa-tourism is a theoretical, economic, geographical, statistical, legal, cultural and social complex'.

This short introduction gives a reader an idea of the present search for a place for tourism among other disciplines. Next, the author will present the positions of those who take the independent tourism discipline option, and then provide his own viewpoint on the issue. The article ends with some reflections on further research into tourism which might be an important step towards interdisciplinarity and away from the currently predominant multi-disciplinary approach which cannot be the basis for developing an independent discipline (CHOJNICKI 2005).

\section{A SINGLE INDEPENDENT DISCIPLINE OF TOURISM STUDIES (nauka o turystyce)}

Before we answer the question of whether a tourism discipline exists, let us remind ourselves of a few epistemological terms, beginning with 'nauka'. In the Dictionary of Polish (Stownik jezyka polskiego - SZYMCZAK ed. 1979), it is defined as 'ogót wiedzy ludzkiej ułożonej w system zagadnien, wyrażonej w sadach prawdziwych i przypuszczeniach' (the whole of human knowledge, arranged in a system of issues, expressed in the form of confirmed facts and assumptions). CHOJNICKI (2005) adds that it is a system built of academic disciplines and fields of knowledge.

If we follow the latter way of thinking, the search for the answer to our original question will come down to stating whether what we call tourism may be regarded as a particular field of study which in turn could be the basis for establishing an independent discipline.

It is commonly accepted that creating a new academic discipline is connected with defining a new field of study, new issues and original study objectives, as well as choosing research methods, defining the range of the discipline (sets of statements regarding the given field of study), and indicating relations with other disciplines (CHOJNICKI 2005).

It appears that in the case of tourism, the most difficult part is in clearly defining the complicated field of study rooted in different natural and social science disciplines and elsewhere. Apart from operational definitions found in every tourism textbook whose aim is to codify tourism and the length of stay outside a tourist's normal residence, researchers examine a multi-faceted phenomenon (which is empirically confirmable $)^{1}$. It refers to an individual and his/ her purposeful movement in space and time, and whose aims are partly or wholly identified with tourism activity. This means that the subject (as well as its academic study) is always the person who travels (Homo Viator), and the field of study is the space, place and time, as well as the various effects and consequences, of this. Researchers should aim at defining, describing, classifying, and most of all, explaining processes, mechanisms and patterns found. The primary aim should be to establish a general theory of tourism, perhaps preceded by formulating partial or specific theories. It should be noticed that in recent years, researchers have become increasingly aware of the necessity to conduct methodological studies which will determine whether an understanding of tourism will consist mainly in recording and describing (as now), or whether it will have a more sophisticated theoretical basis which will allow them to explain it in a comprehensive way. Attempts to consider paradigms (research models) or pretheories seem to be proceeding in the right direction (ALEJZIAK 1999, 2008).

The range of the idea of tourism, which has historical connotations too, is so wide and multifaceted that it is difficult to determine to what extent it is separate from psychological, social, economic, geographical, cultural and other phenomena, or simply occurs independently alongside. Contemporary tourism research is multi-dimensional and representatives of many academic disciplines take part in it.

This difficulty in, or even the impossibility of, precisely defining the field of study, and most of all the lack of a well-defined general theory of tourism (which KAZIMIERCZAK 2005, 2010 sees in the development of tourism 'philosophy'), slows the formulation of a clear definition and methodology of a single tourism discipline. We should mention here an 
interesting work by MAZURKIEWICZ (2005) where he demonstrates the existence of a theory of tourism based on the assumption that it is an empirical discipline.

Representatives of a variety of academic disciplines can be found among those who support tourism as an independent discipline. It is worth quoting the views of MACIOŁEK (2002) who believes that tourism studies has already become sufficiently autonomous to make it an independent discipline which should be treated in the same way as those already recognized in the 'academic pantheon'. He does not suggest a single term for this new discipline, believing that it could be called 'tourism', 'tourismology' (turystykologia) or 'tourism technology' (technologia turystyczna).

A similar point of view (from an evaluation of the considerable research achievements so far) is presented by SIKORA (2001) who believes that it is necessary to establish a tourism discipline and who sees a chance to do so by integrating the results of all the tourism research undertaken by representatives of other academic disciplines. However, in expressing his views, the author does not present any methodological solutions which might lead from the study results to a general theory of tourism.

The author of the present article has also presented his position in the Problemy Turystyki periodical (LISZEWSKI 1994, p. 107), stating that 'the development of the theory and methodology of tourism studies will soon result in the establishment of an independent discipline' (the author as a geographer believed that the definition of tourism suggested by Leszczycki was wide enough to refer to the whole phenomenon). Those predictions turned out to be far too optimistic and today, 15 years later, we are still at the stage of endless discussion ${ }^{2}$.

At the end of this brief review of concepts and ideas regarding the establishment of tourism as an independent discipline, it is worth asking the reasons for doing this. It seems that the most important motive is the lack of opportunity to grant academic degrees in a discipline yet without formal existence which is referred to (still provisionally) as tourism studies (nauka o turystyce). Those who are affected most are graduates of the specialisation entitled 'Tourism and Recreation' (ALEJZIAK 2003; discussion at conferences mentioned earlier), especially at academies of physical education. The same specialisation offered in higher education enables students to follow an academic career in the field of tourism at departments where tourism research is carried out as part of such disciplines as geography, economics, management, pedagogy, sociology, and most probably others as well.

In this situation the question arises of how to create a new academic discipline. Experience gained so far shows that becoming an independent discipline is connected with establishing a particular and original field of study, research issues and methods, as well as clear relations with other disciplines. The 'conditions' for establishing a new discipline do not include distinctive teaching methods as a necessary component. This may mean that when establishing a 'Tourism and Recreation' specialisation in Poland it did not have a strong and well-developed theoretical basis, or that this type of study, practical by nature, requires the participation of representatives of many disciplines for which tourism is a part. The second case, current in the Polish higher education system, implies the necessity not only of multi-disciplinary teaching, but also of creating a system of 'disciplines concerning themselves with tourism' - nauk zajmujacych sie turystyka (tourism disciplines - nauki o turystyce) which would be responsible for formulating a general theory of tourism, an academic basis for educating students in higher education and running interdisciplinary research.

A splendid example of the 'winding roads' travelled by the contemporary scholar is the academic career of a geographer and renowned tourism researcher and member of the International Academy of Tourism, Prof. JANSEN-VERBEKE (2010), which shows how difficult it is to find a place for a new academic discipline dealing with tourism in the contemporary world of higher education and business.

\section{TOURISM STUDIES WITHIN MULTIPLE DISCIPLINES (nauki o turystyce)}

The idea that tourism studies comprises all those disciplines or sub-disciplines which study it in a variety of aspects.

The very use of the plural expression implies that the phenomenon we are discussing is a complex and multi-faceted one, and research into it is multidisciplinary by nature. Using a term in the plural is not exceptional in Polish epistemological classification. The formal titles of higher education departments feature such expressions as nauki geograficzne (geographical 'sciences'), nauki o kulturze fizycznej (physical education), nauki medyczne (medical sciences) or nauki spoteczne (social sciences), usually a result of narrow specialisms developing within a formerly united discipline. They obviously have common roots and, frequently, the same field of study. In order to bring all those narrow sub-disciplines together (sometimes they have developed into fully independent disciplines), a wider name is created which stresses their common origins. An example of such development or, as others see it, the decline of geography are geo- 
graphical 'sciences', in which LESZCZYCKI (1962) identified branches and specialisations. Without going into too much detail, let us mention here only the main geographical ones: physical geography, economic geography, regional geography, cartography, historical geography, the history of geography, mathematical (astronomical) geography and applied geography.

Interdisciplinary disciplines, which emerge as a result of new phenomena, processes and issues in the contemporary world and become a challenge to existing divisions of knowledge, have different origins. A good example could be biotechnology, rooted in a number of basic fields such as biology, chemistry, physics, engineering, medicine and agriculture. Despite the common acceptance of the term 'biotechnology', it is still divided into engineering biotechnology ('black'), medical biotechnology ('red') and biologicalagricultural biotechnology ('green'), depending on the nature and range of a university curriculum, as well as research programmes.

The example of biotechnology, which is 'genetically' closer to 'tourism', shows that the most important aspect of a new discipline is an original issue for researchers to tackle. The name of the discipline (or disciplines) which deals with the new challenge is of secondary importance (though it is also significant).

The theory of the multi-disciplinary character of tourism studies, i.e. acknowledging those academic disciplines which have created tourism studies, is not a new notion. Polish authors usually refer to the work by MACINTOSH \& GOELDNER (1986), while the disciplines involved, with modifications, have also been presented by ALEJZIAK (1999) and MAIK \& PRZYBECKAMAIK (2000).The authors list the following as creating tourism studies - nauki o turystyce (according to a diagram included in both works, moving from north, clockwise): Political Science, Geography, Ecology, Agriculture, Parks and Recreation, Urban Planning, Regional Planning, Marketing, Law, Business and Administration, Transport, Organization and Management, Pedagogy, Sociology, Economics, Psychology and Anthropology. Each of these has a specialisation which runs a tourism studies programme e.g. in Geography it is described as Geografie turyzmu (Tourism Geography), in Law - Prawo w turystyce (Law in Tourism), Economics - Ekonomia turystyki (Tourism Economics), etc.

This scheme confirms that 16 full disciplines and many narrower are linked to tourism. We must remember, however, that these works present the condition of tourism studies in the United States or, broadly speaking, in countries with a well-founded market economy, and they do not show the actual contribution of each to studies of tourism.
An interesting view was presented by MARAK \& WYRZYKOWSKI (2009) stressing the complex character of tourism and point to the 'sciences and arts' (nauki $i$ sztuki) which include the sub-disciplines considered by the Prezydium Państwowej Komisji Akredytacyjnej (State Accreditation Commission) in Poland (Act of $15^{\text {th }}$ July 2007) to be part of 'Tourism and Recreation' studies. To avoid listing all the sub-disciplines, let us quote here only a few which are actually taught at Polish institutions of higher education: Tourism Geography, Tourism Economics, Law in Tourism, Tourism Sociology, Tourism Psychology, History of Tourism, Ecology and Tourism. The Commission mentions other related disciplines such as Architecture, Urban Planning, Computer Science, Transport and Medicine.

The sub-disciplines and disciplines formally regarded in Poland as equal and co-creators of the curriculum of a 'Tourism and Recreation' specialisation confirm the earlier discussion of its multidisciplinary character and are one of the arguments for developing a multiple approach to tourism.

Before we attempt to identify this set of academic disciplines, it seems logical to look closely at the actual phenomenon of tourism itself, mentioned so often in this article. We will follow consecutive elements of this 'coordinated system of elements, sets, which forms a whole, based on a stable, logical ordering of its components' (LISZEWSKI 2005, MAZURKIEWICZ 2005).

In the author's opinion, tourism seen as a system of elements (sets) consists of the following:

- the person who travels (the tourist) - who is the primary subject and the originator of this phenomenon,

- the process of tourism,

- destination and transit places (tourism space),

- the traveller's tourism activity (forms and methods of tourism),

- the effects and consequences of the traveller's journey and stay at each stage of the process.

As such, tourism as a whole and its individual elements (sets) are determined by many internal and external factors (ALEJZIAK 2009).

Assuming that tourism consists of the five elements listed above, we could attempt to identify the academic disciplines which would be helpful or even necessary to discover and describe the processes, mechanisms, rules and regularities of the phenomenon, as well as other research procedures which could lead to formulating a general, commonly accepted theory of tourism.

As was said earlier, the impulse triggering tourism is those who travel and their characteristics. Demographic, physical and mental development, personality, education, family situation, social status, and especially willingness (or need), are the main motives 
to travel for non-earning purposes (one of the crucial conditions for a trip and stay to be considered tourist).

In order for a person to satisfy their needs or fulfil a dream of becoming a tourist, certain conditions must be met. They must enjoy personal freedom, i.e. be able to make decisions concerning themselves. They should not be ill (except for journeys for health reasons) or restrained by their professional or political duties. They must be free in the legal sense (age, rights) and economically (having the financial means to travel), and most of all they must have free time. There are certainly further conditions to be fulfilled, particularly concerning a person's psychology, interests etc.

Man as a tourist is the subject of study mainly, though not exclusively, in humanistic disciplines. Let us mention here psychology, sociology, pedagogy, demography, medicine, economics, law and so on.

By taking a decision to make a temporary change of residence for tourism purposes, we set in motion the process of tourism. Perhaps in the near future we will also use the term 'tourist' to refer to someone who goes on virtual reality trips. Tourism is identified and described by means of certain measures such as quantity, the aim of the journey, the mode of travel, seasonality, length of stay, distance, geographical range, etc. We must be aware that nowadays size and character are among the most important (if not the most important) measures because they comprise social, economic, spatial, organizational, technical and many other aspects.

The academic disciplines studying it are varied; we mention here only those which in Polish conditions have made a contribution in the form of publications: geography, sociology, economics, statistics, communications disciplines, management, history, etc.

An important element of tourism is the destination or a transit place (or area) where tourism activity takes place. The variety of interests and needs of contemporary society is the reason why alongside traditional tourism areas (the coasts of warm seas, mountains, lakes, historical cities) completely new ones, previously disregarded from a tourism perspective (industrial cities, cemeteries, post-military areas, etc.), have appeared. The sites or areas of tourism activity are simultaneously areas where the tourism offer is reflected in actual tourism products. This is seen in the development of an area and its infrastructure, the organization of a stay, satisfying the needs and wishes of the tourist, services provided, etc. The geographical space used by tourists becomes a tourism space which can be classified as either tourism exploration, penetration, assimilation, colonization or urbanization sub-spaces, depending on the intensity and character of exploitation, as well as on the individual qualities of the users themselves (tourists).
The disciplines whose study enriches knowledge of tourism space include geography, environmental protection (environmental biology), regional planning, economics, urban planning, architecture, agriculture, etc.

Tourism studies should by no means disregard those forms of tourism activity which are the essence of spending free time in a chosen place, area or region. Generally speaking, free time devoted to tourism is spent on such activities as getting to know places, taking part in cultural events, entertainment, contemplation and so on.

A detailed analysis of tourism activity and its determinants was carried out by ALEJZIAK (2009) in his post-doctoral thesis which I strongly recommend to those interested. Here, we will only mention a few of the disciplines dealing with this vast and complex issue: physical education, sociology, cultural studies, geography, organization and management.

In order to complete the system, we should unquestionably include the effects and consequences of tourism activity resulting from the journey and stay at each stage of the process. They can be divided into several groups. The first includes the effects of tourism activity for the tourist (improvement of physical and mental condition, learning new things, getting to know new people, entertainment, etc.). The second includes economic effects, mainly for the organizer of the tourism activity, important because economic activity in the form of tourism organization depends on this. The third group concerns the profits and losses to the community (inhabiting the visited areas) in economic, social, cultural and other senses. We may also mention a fourth, the least perceptible, which concerns the annexation, transformation, and often degradation of the local natural and also cultural environment (usually the main element of the tourism offer) which after being exploited becomes a detriment to further development or even the functioning of a locality or area. Some examples of negative effects of tourism activity on tropical islands have been presented by JĘDRUSIK (2005).

The problems of the effects and consequences of tourism activity are mainly dealt with by researchers representing geography, environmental protection, economics, management, sociology, ethnology, cultural studies, history, etc.

The system of elements (sets) making up tourism is in a way similar to the simplified model of the tourist (the ski jump metaphor) presented by JAFARI (1987).

The elements of tourism development, briefly discussed above, do not explain the whole of this complex system, but to present this was not the author's intention. They were only to make the reader aware of the phenomenon being talked about, as well as the senselessness of searching for one, single 
discipline that could tackle the multitude of questions concerning tourism.

The list of 23 academic disciplines or specialisations which should be involved in tourism research is certainly far from being complete. This leads to the reflection that representatives of different academic disciplines dealing with tourism should treat the results of their research with a large dose of humility because it is difficult to point to a single one which might solve all the issues.

The entire discussion above leads to the conclusion that it is interdiscipliniarity that gives a chance for tourism research to be effective, both theoretically and practically. In other words, it should be accepted that we are currently witnessing a process of creating a system of disciplines which can be called tourism studies (nauki o turystyce). It does not mean of course that the final 'composition' of this system, as well as the actual contribution of individual academic disciplines to its theory and solutions to research issues, have already been determined.

To conclude, let us say once again that the opportunity for the theoretical development of tourism studies lies in interdisciplinary research, and not, as now in Poland, in isolated multi-disciplinary work within each (or most) individual academic disciplines.

\section{WHAT IS THE FUTURE OF TOURISM STUDIES?}

Assuming that at present the development of tourism studies is mainly multi-disciplinary, which makes creating a theory of tourism and developing theoretical studies difficult, we should undertake interdisciplinary research which gives us a chance to create a subdiscipline called, for the purposes of this article, tourism studies (nauki o turystyce).

The development of interdisciplinary studies in tourism requires answers to at least two questions. How much do we need to search for rules and regularities in tourism development today? And to what extent should a tourism studies discipline participate in monitoring tourism's determinants and stimulators, and as a consequence in forecasting further tourism development?

These questions show that it is necessary to formulate theoretically and practically significant research issues around which areas of tourism research might be integrated.

It is worth quoting MAIK \& PRZYBECKA-MAIK's (2005) suggestions at this stage. They mention three 'platforms' defining the role of tourism in the contemporary world:

- 'tourism as an economic development factor',
- 'tourism as a factor and result of 'civilization transformation' (przemian cywilizacyjnych)',

- 'tourism as an environmental and spatial transformation factor'.

These 'platforms' require interpreting in terms of detailed research issues which should be based on interdisciplinary discussion among researchers. The author will obviously not attempt here to make a list of the most important current issues, but he wishes to signal a few significant ones, especially in his own field of study (tourism geography) concerning the third 'platform'.

1. The laws of nature vs. tourism space development

For some time the media have been reporting natural disasters which have affected areas used for tourism purposes. It is worth mentioning the disastrous effects of the huge tsunami waves which reached many islands in Indonesia and the countries of South-East Asia, destroying hotels, guest-houses and other elements of the tourism infrastructure, killing hundreds of thousands of people including tourists from different parts of the world. In 2010, television showed the consequences of the intense storms on Madeira which destroyed many tourism areas, while the disaster caused by the explosion of an oil rig in the Gulf of Mexico threatened the tourism region of Florida.

Earthquakes, volcanic eruptions, powerful hurricanes, tsunami, floods and many other extreme phenomena should not cause as many dangers as described in the examples. Such events cannot be prevented or stopped because such are the laws of nature, but we can minimize the losses if we behave wisely and consistently. Building hotels near coastlines, often nearly on the beaches, or lining the bottoms of mountain valleys and streams with concrete for the benefit of tourism, is an attempt to oppose nature, break its rules, and it can end in catastrophe. This problem concerns not only exotic countries, but also Poland.

These examples clearly show that tourism researchers representing different disciplines need to combine forces to research the laws of nature and establish rules regarding tourism development, especially the organization of different types of tourism space (WŁODARCZYK 2009).

2. The protection of the environment and culture vs. tourism development

Empirical studies confirm that legal protection of natural areas and cultural assets increases their attractiveness, and as a consequence the intensity of tourism. This itself then leads to additional dangers to these valuable natural and cultural areas. We witness an inversion of objectives. On the one hand legal 
protection, and on the other social pressure leading to numerous conflicts (e.g. in Ojcowski National Park). It is obvious that without interdisciplinary studies it will be difficult to find a solution which would satisfy all. Tourism organizers should not focus exclusively on creating increasingly attractive tourism products, but also on tourist self-regulation as regards their consumption. It is a very serious and complex problem in an increasingly commercialized world. However, for the sake of the inhabitants of Poland and the international community, it must not remain unresolved.

\section{Creating new tourism spaces}

The fact that people all over the world take part in tourism, while at the same time interests and preferences are changing, means that tourism organizers are looking for new areas which can be transformed into tourism spaces, or new tourism products to attract these new consumers (tourists). This 'race' of tourism organizers in time and space can bring not only a lot of dangers, but also many benefits to the contemporary tourist. New tourism spaces are appearing rapidly and are governed by market rules. It seems necessary to undertake interdisciplinary research into this important phenomenon (LISZEWSKI 2006).

\section{Virtual tourism}

The development of the internet, satellite TV, home cinema and other technological innovations enabling communication over long distances brings a new phenomenon known as 'virtual tourism'.

Looking at the enthusiasm of the younger generation for the internet and other media, we should seriously think about the future of traditional tourism, not only in terms of recreation and getting to know places, but also health. It is an immense research field whose management requires interdisciplinary research because the development of different media attracting millions of young people is extremely rapid. Is this a threat to traditional 'travel'? Will this affect the health of future generations?

The author has indicated here examples of research issues to illustrate his approach and is not presenting a well-developed, detailed analysis.

\section{CONCLUSIONS}

The author has reached the following conclusions:

1. At present there is no theoretical basis for further discussion on the establishment of a single independent academic discipline dealing with the whole 'field of knowledge of tourism'.
2. The author agrees with the idea of an interdisciplinary, and not only multi-disciplinary, approach to tourism research, which may be expressed in the form of tourism studies within multiple disciplines (nauki o turystyce). It remains open to discussion which disciplines could and should constitute this 'discipline consortium'.

3. The element linking 'tourism disciplines' should be the ability to solve theoretical issues by formulating pre-theories (partial theories), or a general theory of tourism, but at the same time tackling and solving important research issues, thus serving both the development of tourism disciplines and the needs of the practical development of tourism in our world.

4. The discussion presented in this article encourages the author to present a few practical solutions aimed at the integration of disciplines dealing with tourism research. It is necessary to make an intellectual and organizational effort in order to assess their credibility and documented contribution in Poland. Such evaluation would allow us to define the ability of 'tourism disciplines' in Poland to tackle such research issues.

5. We should openly discuss the research issues currently faced by Polish tourism researchers, taking into consideration their complexity. This requires interdisciplinary research. Such discussion should integrate researchers around a number of significant research issues.

6. The opinions presented in this article are treated by the author as a contribution to the debate, encouraging readers to think of their own arguments and present their own views on the issues above.

\section{FOOT NOTES}

${ }^{1}$ According to Stownik uniwersalnego jezzyka polskiego (GUBISZ, ed. 2003), a phenomenon is 'something that has occurred or is occurring, that has happened, appeared; a fact, an event. In the theory of science - any object capable of being perceived (empirical fact)'. According to MAZURKIEWICZ (2005) - 'a real phenomenon is a series of changes taking place in time, affecting the features (qualities) of an object, or the qualities and mutual relations within a set of certain real objects'.

2 The author of this mistaken forecast is ready to admit that we are currently at the stage of forming 'tourism disciplines'. A similar view was expressed by Prof. Winiarski at the conference in Łódź, in November 2010.

Translated by Ewa Mossakowska

\section{BIBLIOGRAPHY}

AleJZIAK W., 1999, Turystyka w obliczu wyzwań XXI wieku, Albis, Kraków.

ALEJZIAK W., 2003, Perspektywy i kierunki rozwoju badań naukowych nad turystyką, [in:] G. Gołembski (ed.), Kierunki 
rozwoju badań naukowych w turystyce, Wydawnictwo Naukowe PWN, Warszawa, pp. 231-248.

ALEJZIAK W., 2008, Podstawowe paradygmaty i podejścia badawcze w studiach nad turystyką, [in:] G. Gołembski (ed.), Nowe trendy rozwoju turystyki, Wydawnictwo PWSZ, Sulechów, pp. 13-25.

ALEJZIAK W., 2009, Determinanty i zróżnicowanie społeczne aktywności turystycznej, Studia i Monografie AWF Kraków, no. 56.

CHOJNICKI Z., 2005, Charakter i sytuacja nauki o turystyce - rozważania metodologiczne, Zeszyty Naukowe Wyższej Szkoły Gospodarki w Bydgoszczy, vol. 3, no. 2, pp. 11-23.

DuBISZ S. (ed.), 2003, Uniwersalny stownik języka polskiego, vol. 4 (T-Z), Wydawnictwo Naukowe PWN, Warszawa.

GOŁEMBSKI G. (ed.), 2003, Kierunki rozwoju badań naukowych $w$ turystyce, Akademia Ekonomiczna w Poznaniu, Wydawnictwo Naukowe PWN, Warszawa.

JAFARI J., 1987, System turystyki. Społeczno-kulturowe modele do zastosowań teoretycznych, Problemy Turystyki, no. 3, pp. 3-17.

JANSEN-VERBEKE M., 2010, Moja droga naukowa: Od geografii do turyzmu, od turyzmu do geografii turyzmu, Turyzm, vol. 20, no. 1, pp. 69-73.

JĘDRUSIK M., 2005, Wyspy tropikalne. W poszukiwaniu dobrobytu, Wydział Geografii i Studiów Regionalnych Uniwersytetu Warszawskiego, Warszawa.

KAZIMIERCZAK M., 2005, Filozofia turystyki a integracja nauk o turystyce, Akademia Ekonomiczna w Poznaniu, Wydawnictwo Naukowe PWN, Warszawa.

KAZIMIERCZAK M., 2010, O autonomii nauk w turystyce, [in:] S. Tanaś (ed.), Nauka i dydaktyka w turystyce i rekreacji, Łódzkie Towarzystwo Naukowe, Łódź, pp. 11-20.

LESZCZYCKI S., 1962, Rozwój myśli geograficznej, [in:] Geografia powszechna, vol. 1, Wydawnictwo Naukowe PWN, Warszawa.

LISZEWSKI S., 1994, Perspektywy badań naukowych w zakresie turystyki w Polsce $\mathrm{w}$ najbliższym dziesięcioleciu, Problemy Turystyki, vol. XVII, no. 3/4, pp. 105-111.

LISZEWSKI S., 2005, Koncepcje zintegrowanych badań nad turystyką, [in:] B. Domański, S. Skiba (ed.), Geografia i sacrum, vol. 2, IGiGP UJ, Kraków, pp. 105-113.
LISZEWSKI S., 2006, Przestrzenie turystyki i transformacja we współczesnym świecie, Turyzm, vol. 16, no. 2, pp. 7-19.

ŁOBOŻEWICZ T., 2001, Miejsce turystyki w naukach o kulturze fizycznej, Zeszyty Naukowe AWF w Krakowie, no. 31, pp. 13-20.

MACIOLEK R., 2002, Osobliwości metodologiczne badań nad turystyką, Zeszyty Naukowe Wyższej Szkoły Turystyki i Hotelarstwa, no. 2, pp. 17-26, Bydgoszcz.

MCINTOSH R.W., GOELDNER Ch.R., 1990, Tourism. Principles, Practises, Philosophies, John Wiley \& Sons, New York.

MAIK W., PRZYBECKA-MAIK M., 2005, Główne czynniki i płaszczyzny integracyjne w naukach o turystyce, Turystyka i Rekreacja, Zeszyty Naukowe Wyższej Szkoły Gospodarki w Bydgoszczy, vol. 3, pp. 25-32.

MARAK J., WYRZYKOWSKI J., 2009, Turystyka jako przedmiot interdyscyplinarnych badań naukowych, Zeszyty Naukowe Uniwersytetu Szczecińskiego, no. 567, Ekonomiczne Problemy Turystyki, no. 12, pp. 165-180.

MAZURKIEWICZ L., 2005, Czy istnieje teoria turystyki?, Problemy Turystyki, vol. XXVIII, no. 3/4, pp. 155-167.

MAZURKIEWICZ L., 2009, O przedmiocie turystyki i rekreacji, Turystyka i Rekreacja, AWF Warszawa, vol. 5, pp. 80-91.

SIKORA J., 2001, Potrzeba wyodrębnienia nauk o turystyce, Zeszyty Naukowe AWF w Krakowie, no. 81, pp. 81-83, Kraków.

SZYMCZAK M., (ed.) 1979, Stownik języka polskiego, vol. 2, Państwowe Wydawnictwo Naukowe, Warszawa.

WINIARSKI R., (ed.), 1999, 2004, Nauki o turystyce, Studia i Monografie, no. 7 (part 1 and 2), AWF, Kraków.

WINIARSKI R., ALEJZIAK W. (ed.), 2005, Turystyka w badaniach naukowych, AWF Kraków, Wyższa Szkoła Informatyki i Zarządzania w Rzeszowie, Kraków, Rzeszów.

WŁODARCZYK B., 2009, Przestrzeń turystyczna. Istota, koncepcja, determinanty rozwoju, Wydawnictwo Uniwersytetu Łódzkiego, Łódź.

WOŹNIAK A., 2005, Socjologiczna analiza turystyki - poszukiwanie syntezy, Turystyka i Rekreacja, Zeszyty Naukowe Wyższej Szkoły Gospodarki w Bydgoszczy, vol. 3, pp. 4552. 